\title{
Management Accounting Systems and Organizational Performance of Nepalese Commercial Banks
}

\begin{abstract}
Achyut Gnawali, PhD
ABSTRACT

Management accounting information plays a vital role in these basic management activities but most particularly in planning, decision making, costing and control functions. The purpose of this study was to examine the effect of management accounting systems on organizational performance in Nepalese commercial banks. Descriptive and casual research design has been adopted. Questionnaires and published documents are used to collect the data. It was found that management accounting systems have affected the performance of sample organizations.
\end{abstract}

Keywords: Commercial banks, costing, decision making, MAS, performance evaluation

\section{Introduction}

Every successful organization must employ an effective accounting information system. The effective accounting information system ensures that the every accounting as well as related activities is going on properly and according to plan. It helps to find out the deviation and take corrective action and ensures efficient and effective management system. In the search to understand management accounting in competitive environments and advance technologies, change has increasingly become a focus for research every organization large and small has managers. Someone must be responsible for making plans, organizing resources directing personnel and controlling operations. Everywhere managers carry out three major activities planning, directing and motivating and controlling.

Johnson and Kaplan (1987) described how a management accounting system must provide timely and accurate information to facilitate efforts to control costs, to measure and improve productivity, and to devise improved production processes. The management accounting system must also report accurate product costs so that pricing decisions, introduction of new products, abandonment of obsolete products, and response to rival products can be made.

Wilson (1997) argues that the role of accounting is to serve the needs of strategic management. Several writers have demonstrated how accounting in involved in processing now strategic orders insides the firm.He (1997) pointed out the use of management accounting information to support strategy decision making and also the impact that information can have on organizational outcomes. Strategic management accounting is the process of identifying, gathering, choosing and analyzing accounting data for helping the management team to make strategic decisions and to assess organizational effectiveness (Hoque, 2001:2).

Johnson, (1981)defined management accounting as a system of measuring and providing operational and financial information that gives managerial action, motivates behaviors and 
supports and creates the cultural values necessary to achieve an organization's strategic objectives.

Managers of different levels in an organization take several different decisions and actions far effectively and efficiently realizing goals and objectives of the organization. In today's highly turbulent and intense competitive organizational environment, the managers and strategists have to set strategic goals and objectives, formulate strategic plans, implement and control them, and make several strategic decisions. For all this, they use reliable and valid accounting information available in the organization. Management accounting provides the pertinent and reliable information in order to get make right decision in right time with systematic manner.

\section{Research Questions}

The following are the key research issues towards which this study has been directed.

- What is the practice of management accounting system in Nepalese Commercial Banks?

- Is there a relationship between the use of management accounting system and the Performance of Nepalese Commercial Banks?

\section{Objective of the Study}

The main purpose of this study is to analyze the management accounting systems and organizational performance in Nepalese Commercial Banks. More specifically this study proposes following specific objectives:

- To examine the practices of management accounting system in Nepalese commercial banks.

- To examine the relationship between the use of management accounting systems and the organizational performance of Nepalese commercial banks.

\section{Theoretical Framework}

\begin{tabular}{|l|l|}
\hline $\begin{array}{l}\text { Management Accounting System } \\
\text {-Controlling and reporting } \\
\text {-Planning and budgeting } \\
\text {-Decision making } \\
\text {-Performance evaluation system } \\
\text {-Costing systems }\end{array}$ & $\begin{array}{l}\text { Performance } \\
\text {-Employees' Perceived } \\
\text { Organizational } \\
\text { performance }\end{array}$ \\
\end{tabular}

Independent Variables

Dependent Variable 
evaluation system, decision making system, costing system. The theoretical framework is shown in Figure 1..

From the above theoretical framework it has been conceptualized that budgeting and planning, controlling and reporting, performance evaluation system, decision making system, costing system(Management accounting systems) have positive correlation

\section{Review of Literature}

The majority of the studies have dimensioned Management Accounting Systems to costing systems; budgeting, decision making, performance evaluation and controlling and reporting.

\section{Costing}

Research indicates that the information on product costs generated by costing systems has a wide number of uses. It includes pricing decisions; cost control (Yoshikawa et al 1989; Van Triest and Elshahat, 2007); an evaluation of production processes; and transfer pricing (Yoshikawa et al 1989). The two main costing methods adopted were absorption costing and direct (variable) costing in previous researches. Absorption costing system is general preferred globally (Drury et al. 1993, Scherrer, 1996), Shields et al. 1991). Joshi (2001) reported half of Indian firms adopted this technique and Firth (1996) revealed 66\% of Chinese foreign-based companies applied this technique. Likewise, the use of direct (variable) costing is also widespread. Similarly, Abdel-Kader and Luther (2006) indicated just over 50\% of British firms implemented this technique. In contrast, in developing countries, Firth (1996) reported an adoption rate of $76 \%$ by locally based Chinese companies in China. Contrary to the results in European countries and developing countries, U.S and Australia, results reveal a much higher uptake of Activity Based Costing systems.

\section{Budgeting}

Budgeting is perceived as an important control system in almost all organizations (Hansen and Van der Stede, 2004). The main focus on budgeting has been on uptake rates and the purposes underlying its use.Previous research indicates that the main purposes of budgeting are planning future performance; planning the future financial position; planning future cash flows; planning future day to day operations; and controlling costs (Chenhall and LangfieldSmith, 1998; Abdel-Kader and Luther, 2006).

\section{Performance Evaluation}

Emmanuel et al. (1990) noted that performance evaluation was an important function of management accounting. Performance evaluation provides information for managers to support the achievement of their organization's strategic objectives (Jusoh and Parnell, 2008). Hall (2008) argued that in recent years organizations have sought to develop more comprehensive performance measurement systems (PMS) to provide managers and employees with information to assist in managing their operations. Hall (2008) also stated 
popular techniques for delivering a wider set of performance measures are the balanced scorecard (Kaplan and Norton, 1996), and performance hierarchies (Lynch and Cross, 1992). CIMA (2002) highlighted the frameworks for performance measurement and management which are the value-based management (VBM); ABC and activity-based management; balanced scorecard; European Foundation for Quality Management (EFQM) excellence model; benchmarking; strategic enterprise management (SEM); and six sigma. However the literature indicates that in general both financial and non-financial measures are used to measure performance (Gomes et al. 2004). Financial measures such as return on investment (ROI) and profit measures were extensively used in most countries: in U.K (Abdel-Kader and Luther, 2006); in Japan (Abdel-Maksoud et al. 2008); in Singapore Ghosh and Kai-Chan (1997); in India (Joshi, 2001).

\section{Decision Making}

Wu et al. (2010), hold that effective decision making is the most important key factor in today's rapid and changing competitive environment. The decision support analysis can be divided into short term and long term analysis. Abdel-Kader and Luther (2006) argued that for regular or short-term decisions management accountants can use cost-volume-profit (CVP) analysis, product profitability analysis, customer profitability analysis, and stock control models. For longer-term capital investment decisions management accountants can produce and review accounting rates of return and payback periods as well as complex signals based on discounted cash flow. Capital budgeting techniques capture both non-discounted and discounted approaches. Drury et al. (1991) argued that the superiority of internal rate of return (IRR) and net present value (NPV) analysis has been repeatedly demonstrated under conditions of certainty.

\section{Controlling and Reporting}

Anthony (1965) defined control is the process of assuring that resources are obtained and used effectively and efficiently in the accomplishment of the organization's objectives. It is a function that compares achieved results with planned goals. The control function is the process of ordering, evaluating, and providing feedback to the management system of an organization. The environment in which modern organizations operate are becoming more and more complex - more products, more players, and rapidly changing technology and markets. As a result of this complexity, no single individual or group can evolve a solution, which is considered effective. Hence, the need for an integrated system of management control arises (Gyawali, 2005).Control refers to monitoring and evaluation of performance to determine the degree of conformance of actions to plans. Ideally, planning precedes control, which is followed by a feedback corrective action or a feed forward preventive action.

\section{Management Accounting Practices and Performance}

There is strong empirical support for the association between management accounting practice and performance, with an increased use of non-financial information. Baines and LangfieldSmith (2003) show that a greater reliance on non-financial accounting information resulted in 
improved organizational performance.Chenhall and Langfield-Smith (1998) found a greater use of advanced management accounting practices, such as quality improvement programs, benchmarking and activity-based management, in firms that placed a strong emphasis on product differentiation strategies, ultimately resulting in high performance.According to management accounting system information and requirement of decision maker will improve the decision quality to be taken and in the end will improve the strategic business unit performance. Mia and Clarke's (1999) expressed the usefulness of management accounting system information that could assist the company for the implementation of their plans in response of competitive environmental. Management accounting system information by managers can assist them in making more accurate decision, which will lead to improvement in performance (Mia, 1993, Chenhall and Morris, 1995).Sim\&Killough (1998), Mia (2000), . Similarly, Patiar and Mia (2008) indicate that the interaction effect of market competition and the use of management accounting system information enhance the non-financial performance of hotels.

Realizing the usefulness of management accounting system, the current studies also postulates the positive relationship between management accounting system and organizational performance.

\section{Research Methodology}

This study used a quantitative approach towards descriptive and explanatory casual research design for the empirically speculating the research questions for this study. The target population identified for gathering information regarding this concern is Nepalese Commercial Banks from among the firms in the various industries that comprise the service sector. There were 31 banks at the time of selection of sample of this study. Out of these 31 banks only 17 numbers of banks were established before 2002. The selection of the bank for the study was framed on the basis of ten years in operations. Furthermore, six earliest established Nepalese commercial banks were selected for the study. These banks were established between 1937 and 1993. In the sampling framework, samples of employees and Top level management representatives were taken for the study. Furthermore, the sample of employees were selected in convenience sampling techniques. Keeping in view the objectives of this study both primary and secondary sources of data have been used in this study. The sources for primary data are different levels of employees and management representatives of the bank. According to the Annual Report of the Banks, there were 8248 total numbers employees in these banks. Accordingly, the sample size determined was 367 numbers of employees using sample size calculator. The overall field work for data collection was undertaken from January 2013 to July 2014. The questionnaire designed for the purpose of data collection from the respondents. One of these questionnaires was designed for employees of the banks .

\section{Employees' Questionnaire}

At the outset, the independent variables of Management Accounting System includes Budgeting \& Planning, Controlling \& Reporting, Decision support system, Costing system and Performance Evaluation. The questionnaire includes 96 opinion statements. The statements 
were developed under the four main variables with relevant literatures review. Management accounting system variable has 45 opinion statements, Performance variable has 6 opinion statements. Likert 5 point scale (with $5=$ strongly, 4=Agree, 3=Neutral, 2=Disagree and $1=$ Strongly Disagree) has been used.

\section{Reliability and Validity}

Nunnally (1978) suggested that alpha coefficients of 0.50 to 0.60 will be deemed acceptable for exploratory research.An opinion leader survey was conducted to design and pre-test the questionnaire. The Cronbach“s $\alpha$ for overall Management Accounting system was 0.948 (highly reliable), and for overall Performance was 0.821 (highly reliable).

\section{Techniques of Analyses for Primary Data}

The primary data collected were cleaned, tabulated and analyzed using the software SPSS $\mathrm{V}-22$. The data collected in this study was used to generate descriptive statistics as well as inferential statistics. For the same purpose an Exploratory Factor Analysis with extraction method of Principal Component Analysis was used. For the purpose of sampling adequacy KMO and Bartlett's test of specify were also utilized.

\section{Discussion and Results}

\section{Overall Management Accounting System Practice in Commercial Banks}

Table 1, presents the overall management accounting system variables descriptive statistics. The result shows that the highest mean of respondents among different management accounting system variables regarding different statements is $3.75(\mathrm{SD}=0.681)$ and the lowest mean was $3.53(\mathrm{SD}=0.586)$ of costing system. It falls under agreed band and mean of almost all the statement is greater than test value (3). That means all opinion statements are important variables. To test the significant difference from the mean score, the $\mathrm{p}$ value of all opinion statements resulted in $0.001(<0.01)$, which indicates that all the statements are significant variables.

Table 1: Respondents' View on Management Accounting System in Commercial Banks

Test Value $=3.00$

Variables of Management

Accounting System

Std. t value $\mathrm{p}$ Remarks

Budgeting and Planning

N Mean Deviation

value

Controlling and Reporting

507

3.755

.681

$24.947 \quad 0.001$

Significant

Decision Making System

$507 \quad 3.595$

.593

$22.583 \quad 0.001$

Significant

Costing System

$507 \quad 3.601$

.568

$23.793 \quad 0.001$

Significant

Performance Evaluation

$507 \quad 3.532$

.587

$20.406 \quad 0.001$

Significant

$507 \quad 3.561$

.614

$20.553 \quad 0.001$

Significant 


\section{Organizational Performance of the Commercial Banks}

The output result of mean which is show in Table 2 indicates the highest grand mean of respondents regarding Performance to $3.730(\mathrm{SD}=0.626)$. It can be interpreted as under agreed band and the mean of almost all the opinion statement is greater than test value. To test the significant difference from the mean score, the $p$ value of all opinion statement comes out to be $0.001(<0.01)$, which indicates that all the statements are significant variables. Collective performance consisted of different components such as profitability, productivity, effective decision making, strong financial position service delivery and quality, exploitation of new business opportunities, customer satisfaction, achieve competitive advantage etc. The result showed that the overall status was satisfactory with majority agreeableness to the extent of organizational performance.

Table 2: Respondents' View on Performance in Commercial Banks

\begin{tabular}{llccrrrr}
\hline & & \multicolumn{3}{c}{ Std. Devia- } & \multicolumn{3}{c}{ Test Value $=3.00$} \\
Dependent Variable & $\mathrm{N}$ & Mean & tion & t value & p value & Remarks \\
Performance & 507 & 3.730 & .626 & 26.23 & 0.001 & Significant \\
\hline
\end{tabular}

The output presents figures relating to the test for sampling adequacy (KMO) and the test of sphericity. KMO statistics is 0.938 , which suggests that a factor analysis can be performed with a data set of the number of observations and the variables. Each of the factors has been named as Budgeting and Planning, Decision Making and Costing System, Performance Evaluation, Controlling \& Reporting and Customer \& Market Retention.

\section{Impacts of management accounting system on Organizational Performance}

Since the relationship between Management Accounting Systems to Organizational Performance has been established in this study, further, this study also focused on examining the effect of changes in Management Accounting Systems over Organizational Performance. The regression analysis was done in SPSS v22 with the following regression model.

\section{Multiple Regression Model-: Management Accounting System to Organizational Performance}

The result shows that there is a significant impact of Management Accounting Systems on Organizational Performance. It shows a significant association between the changes in Management Accounting Systems on Organizational Performance. The finding of multiple regression analysis between Management Accounting System and Organizational Performance indicates that Management Accounting System is a significant predictor of Organizational Performance. The $\mathrm{R}$ value of 0.693 indicates the moderate to strong positive relationship between Management Accounting System and Organizational Performance ( $F=33.03, p<0.01)$. Similarly,R-square value of 0.443 states that $44.3 \%$ change in performance is due to combined independent variables. Likewise, Standard error of the estimate of 0.535 indicates the variability of the observed value of Organizational Performances from regression line is 0.535 units. Since VIF of each of independent variables is less than 10 , there is no problem of multicollinearity 
in this model. Thus, it was shown that there is significant correlation between Management Accounting System and significantly predict organizational Performance. All the variables of Management Accounting System are significantly influences the dependent variable performance except Controlling and Reporting. The variable of Management Accounting System viz., Budgeting and Planning has an impact of $24.7 \%$, Decision Making and Costing System has an impact of $32.1 \%$, Performance Evaluation has an impact of $1.3 \%$, Controlling and Reportinghas an impact of $-3.3 \%$, Customer and Market Retention has an impact of 1.2\% contributed towards Organizational Performance.

Table 3: Model Summary of Management Accounting Systems on Organizational Performance

\begin{tabular}{cccccccc}
\hline Model & $\mathrm{R}$ & $\mathrm{R}$ & Adjusted & Std. Error of & Durbin- & $\mathrm{F}$ & $\mathrm{p}$ value \\
& & Square & R Square & $\begin{array}{c}\text { the Estimate } \\
\text { Watson }\end{array}$ & & \\
1 & $.693^{\mathrm{a}}$ & .443 & .430 & .535 & 1.974 & 33.030 & .001 \\
\hline
\end{tabular}

a. Predictors: (Constant), Budgeting and Planning, Decision Making and Costing System, Performance Evaluation, Controlling and Reporting, and Customer and Market Retention b. Dependent Variable: Organizational Performance

Table 4: Multiple Regression Analysis: CoefficientsP ${ }^{a}$

\begin{tabular}{|c|c|c|c|c|c|c|c|}
\hline $\begin{array}{l}\text { Management } \\
\text { accounting system }\end{array}$ & \multicolumn{2}{|c|}{$\begin{array}{l}\text { Unstandardized } \\
\text { Coefficients }\end{array}$} & $\begin{array}{l}\text { Standardized } \\
\text { Coefficients }\end{array}$ & $\mathrm{t}$ & Sig. & \multicolumn{2}{|c|}{$\begin{array}{l}\text { Collinearity } \\
\text { Statistics }\end{array}$} \\
\hline $\begin{array}{l}\text { as a predictor of } \\
\text { Performance }\end{array}$ & B & $\begin{array}{l}\text { Std. } \\
\text { Error }\end{array}$ & Beta & & & Tolerance & VIF \\
\hline (Constant) & 1.687 & .178 & & & & & \\
\hline $\begin{array}{l}\text { Budgeting and } \\
\text { Planning }\end{array}$ & .247 & .046 & .268 & 5.337 & .001 & .598 & 1.672 \\
\hline $\begin{array}{l}\text { Decision Making } \\
\text { and Costing System }\end{array}$ & .321 & .066 & .298 & 4.874 & .001 & .404 & 2.474 \\
\hline $\begin{array}{l}\text { Performance } \\
\text { Evaluation }\end{array}$ & .013 & .051 & .013 & .254 & .007 & .569 & 1.756 \\
\hline $\begin{array}{l}\text { Controlling and } \\
\text { Reporting }\end{array}$ & -.033 & .058 & -.031 & -.566 & .571 & .491 & 2.038 \\
\hline $\begin{array}{l}\text { Customer and } \\
\text { Market Retention }\end{array}$ & .012 & .042 & .015 & .288 & .007 & .552 & 1.812 \\
\hline
\end{tabular}

a. Dependent Variable: Organizational Performance

From the above results, the estimated equation can be written by taking the values from the

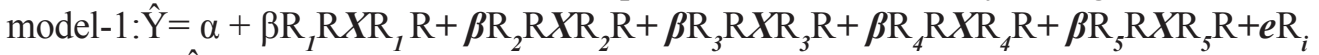
Therefore, $\hat{\mathrm{Y}}=1.687+0.247 * \mathrm{XR}_{1} \mathrm{R}+0.321 * \mathrm{XR}_{2+} \mathrm{R} 0.013 * \mathrm{XR}_{3} \mathrm{R}-0.033 * \mathrm{XR}_{4+} \mathrm{R} 0.012 *$ $\mathrm{XR}_{5}$

It is observed that the t-values of four variables are statistically significant at $1 \%$ level namely Budgetingand Planning, Decision Making and Costing System, Performance Evaluation, and 
Customer \& Market Retention. This suggests that these variables have a bearing on explaining the variability of organization performance. However; the variable Controlling and Reporting is not statistically significant. Hence, there is sufficient evidence that Management Accounting Systems has a positive impact on organizational performance (Scherrer ,1996).

Hence, there is enough evidence thata change in Management Accounting Systems improve theorganizational Performance.

The detail results of the analysis are presented in the table 3.

\section{Summary and Conclusion}

The banking sector is the most prominent one in the financial sector, it is the fastest growing sector in Nepal in the last two decades. Financial liberalization and technological revolution intensify the competitive pressures among the financial institutions. Well-designed Management Accounting System can more effectively and efficiently lead an organization towards higher performance.

The purpose of this research was empirically analyzed the relationship of Management Accounting System, and Organizational Performance outcome. The present scenario of management accounting system in Nepalese commercial banks has moderately utilized. The perception of employees' towards the dimensions of management accounting system in a nutshell can be understood with a mean score of 3.75 ( $\mathrm{SD}=0.681)$. Likewise, in terms of the dimension including Budgeting \& Planning, Controlling and Reporting, Decision support system, Costing system and Performance Evaluation, the lowest mean score of 3.53 $(\mathrm{SD}=0.586)$ was for costing system. The mean score for Budgeting and Planning practice in commercial banks was $3.755(\mathrm{SD}=.681)$. The manager makes plan about detecting\& correcting irregularities become more effective for controlling and reporting in Nepalese commercial banks. Hence, the commercial banks of Nepal detect \& correct irregularities for effective management accounting system. However, the concern is the measuring performance against target is lacking. The mean score for Decision Making System in commercial banks was 3.601 $(\mathrm{SD}=.5684)$. The managers make good decision that increases market share, productivity and profit. That is, commercial bank of Nepal makes right decision for effective management accounting system. However, the participation in decision making on merger and acquisition was not so encouraging. The mean score for Costing System practice in commercial bank was $3.532(\mathrm{SD}=.587)$. The manager reduces cost in functional areas i.e. production, operational, finance, marketing and research and development.

\section{Change in management accounting systems improves organizational performance}

The findings in this study show the evidence that an alignment among changes in management accounting system significantly improves organizational performance. That is management accounting system significantly increases performance of the banks. Since the relationship between management accounting systems to organizational performance has been established in this study. The findings indicate that there is a significant impact of management accounting 
systems on organizational performance. A change of $44.3 \%$ in organizational performance has been seen due to management accounting systems. All the variables of management accounting system are significantly influential to the organizational performance. There is wellestablished empirical evidence for an association and impact between management accounting system and organizational performance. Hence, there is sufficient evidence that management accounting systems has a positive impact on organizational performance Scherrer, (1996).

\section{Conclusion}

The purpose of this research was to identify the relationships between management accounting system, and organizational performance. The overall picture emerging from the study is based on the theoretical framework according to the literatures and applied to Nepalese commercial banking environment. Focusing on the alignment among management accounting system, and organizational performance, this study addressed empirically to the research questions formulated. It has been done with descriptive and casual relationship between the measures and their impacts on organizational performance. The conclusions reached from the results of this study have profound implications for both theory and practice. Based on the findings, it is concluded that the model adopted is generally applicable in Nepalese context. Based on the findings, it is concluded that the model adopted is generally applicable in Nepalese context. Positive relationship of management accounting system to organizational performance. MAS is a significant predictor of organizational performance.

This result is consistent to the results of Gul (1991), Chenhall and Morris (1995), in which they concluded that AIS (MAS) contribute to performance in high perceived environmental uncertainty situation, which involves highly competitive actions and market demand. Likewise, Chenhall and Morris (1995) concluded with empirical findings that there is an impact of management accounting system on the organizational performance .

\section{Managerial Implications}

Since globalization, liberalization, privatization, modernization and competition are the five pillars for strengthening the financial sector; these concepts should be adhered to all the time in developing strategy for Nepalese commercial banks. These dimensions has opened Nepalese banking industry towards a greater competition and application of Management Accounting System towards formulating and implementing organizational strategy, to create a significant comprehensive organizational performance.

Similarly, the corporate governance and corporate social responsibility issues are vital to different sectors of the economy, inclusive banking sector. The life of the organization always depends on its way for governance, while Management Accounting Systems support good governance and can be implemented in Nepalese commercial banks. The requirement of adequate disclosures and transparency for effective decision making should be supported by strong Management Accounting System. 


\section{Implications for Future Research}

With this research on the relationship between management accounting system and organizational performance, this area is ripe for futureresearch. As is common in survey research, data are cross-sectional and self-report. There are several significant issues to be considered for future research. In order to improve the future study, the sample size could be collected from the manufacturing firms across the country (Nepal). Therefore, the new findings of manufacturing sector can give a new direction in understanding the subject phenomenon. Further research might be carried out with more sample of banks, as this study only based on six commercial banks of Nepal. In addition, a step further, Structural Equation Modeling approach of data analysis may be taken into account to moderating or mediating factors.

Therefore, it would be interesting to expand the survey to provide longitudinal survey of management accounting change documenting changes overtime in the adoption of strategy and significant influence of the performance of the banks.

\section{BIBLIOGRAPHY}

Abdel-Kader, M., \& Luther, R. (2006). Management accounting practices in the British food and drinks industry. British Food Journal, 108(5), 336-357.

Chenhall, R. H., \& Morris, D. (1995). Organic decision and communication processes and management accounting systems in entrepreneurial and conservative business organizations. Omega, International Journal of Management Science, 23(5), 485- 497.

CIMA. (2005). Management Accounting Official Terminology. The Chartered Institute of Management Accountant.

Emmanuel, C., Otley, D., \& Merchant, K. (1990). Accounting for Management Control. London: Chapman \& Hall.

Firth, M. (1996). The diffusion of managerial accounting procedures in the People's Republic of China and the influence of foreign partnered joint ventures. Accounting, Organizations and Society, 21(7/8), 629-54.

Hall, M. (2008). The effect of comprehensive performance measurement systems on role clarity, psychological empowerment and managerial performance. Accounting, Organizations and Society, 33, 141-163.

Hoque, Z. (2005). Linking environmental uncertainty to non-financial performance measures and performance: A research note. The British Accounting Review, 37(4), 471-481.

Gul, F. A. (1991). The effects of Management Accounting Systems and Environmental Uncertainty on Small Business Managers' Performance. Accounting and Business Research, 22(85), 57-61.

Ghosh, B. C., \& Chan, Y. K. (1997). Management accounting in Singapore-well in place? Managerial Auditing Journal, 12(1), 16-18.

Gyawali A.(2005) Management Control Systems in Nepalese Organizations, Unpublished Thesis Submitted To Faculty Of Management ,TU.

Ittner, C. D., Larcker, D. F., \& Randall, T. (2003). Performance implications of strategic performance measurement in fi nancial service fi rms. Accounting, Organizations and Society, 28(7=8), $715-741$. 
Johnson, H. T., \& Kaplan, R. S. (1987). Relevance Lost: The Rise and Fall of Management Accounting. Boston, Massachusetts: Harvard Business School Press.

Johnson, H. T. (1981). Toward a New Understanding of Nineteenth-Century Cost Accounting. The Accounting Review, 56(3), 510-518.

Joshi, P. L. (2001). The international diffusion of new management accounting practices: the case of India. Journal of International Accounting, Auditing and Taxation, 10, 85-109.

Jusoh, R. (2006). The usage of balanced scorecard measures, business strategy and firm performance. $\mathrm{PhD}$ dissertation, University Sains Malaysia, Malaysia.

Lynch, R. L., \& Cross, K. F. (1991). Measure Up! Yardsticks for Continuous Improvement. London, U.K: Blackwell.

Lukka, K., \& Granlund, M. (1996). Cost accounting in Finland: current practice and trends of development. The European Accounting Review, 5, 1-28.

Mia, L. (1993). The role of MAS information in organizations: An empirical study. British Accounting Review, 25, 269-285.

Mia, L. (2000). Just-in-time manufacturing, management accounting systems and profitability. Accounting and Business Research, 30(2), 137-151.

Mia, L., \& Brian, C. (1999). Market Competition,Management Accounting Systems and Business Unit Performance. Management Accounting Research, 10, 137-158.

Morris, T. (1986). Innovations in Banking: Business Strategies for Employee Relations. Beckenham, Kent, UK: Croom Helm .

Patiar, A., \& Mia, L. (2008). The interactive effect of market competition and use of MAS information on performance: Evidence from the upscale hotels. Journal of Hospitality and Tourism Research, 32(2), 209-234.

Roslender, R., \& Hart, S. (2003). In search of strategic management accounting: Theoretical and field study perspectives. Management Accounting Research, 14(3), 255-279.

Scherrer, G. (1996). Management accounting: a German perspective. In A. Bhimani, Management Accounting: European Perspectives (pp. 100-122). Oxford, UK: Oxford University Press.

Sim, K. L., \& Killough, L. N. (1998). The performance effects of complementarities between manufacturing practices and management accounting systems. Management Accounting Research, 10, 325-346.

Van Triest, S., \& Elshahat, M. F. (2007). The use of costing information in Egypt: a research note. Journal of Accounting and Organizational Change, 3(3), 329-343.

Wilson, R. M. (1997). Strategic cost management. Dartmouth: Ashgate.

$\mathrm{Wu}$, J., \& Boateng, A. (2010). Factors Influencing Changes in Chinese Management Accounting Practices. Journal of Change Management, 10(3), 315-329.

Yoshikawa, T. (1994). Some aspects of the Japanese approach to management accounting. Management Accounting Research, 5, 279-89. 